\title{
Modelling Tools to Analyze and Assess the Ecological Impact of Hydropower Dams
}

\author{
Thi Hanh Tien Nguyen ${ }^{1,2}$, Gert Everaert ${ }^{1,3} \mathbb{( B}^{\circ}$, Pieter Boets ${ }^{1,4} \mathbb{( D}^{(0)}$, Marie Anne Eurie Forio ${ }^{1, *}$, \\ Elina Bennetsen ${ }^{1}(\mathbb{D})$, Martin Volk $^{5}{ }^{(\mathbb{D})}$, Thu Huong Thi Hoang ${ }^{6}$ and Peter L. M. Goethals ${ }^{1}$ \\ 1 Laboratory of Environmental Toxicology and Aquatic Ecology, Ghent University, Coupure Links 653, \\ B-9000 Ghent, Belgium; hanhtienait8@gmail.com (T.H.T.N.); gert.everaert@vliz.be (G.E.); \\ pieter.boets@oost-vlaanderen.be (P.B.); elinabennetsen@gmail.com (E.B.); peter.goethals@ugent.be (P.L.M.G.) \\ 2 \\ 3 Flanders Marine Institute, Wandelaarkaai 7, B-8400 Ostend, Belgium \\ 4 Provincial Centre of Environmental Research, Godshuizenlaan 95, 9000 Ghent, Belgium \\ 5 Department of Computational Landscape Ecology, UFZ-Helmholtz Centre for Environmental Research, \\ Permoserstr. 15, 04318 Leipzig, Germany; martin.volk@ufz.de \\ 6 School of Environmental Science and Technology, Hanoi University of Science and Technology, \\ Hanoi 100000, Vietnam; huonghtt@yahoo.com \\ * Correspondence: Marie.Forio@UGent.be; Tel.: +32-09-264-3708
}

\begin{abstract}
We critically analyzed a set of ecological models that are used to assess the impact of hydropower dams on water quality and habitat suitability for biological communities. After a literature search, we developed an integrated conceptual model that illustrates the linkages between the main input variables, model approaches, the output variables and biotic-abiotic interactions in the ecosystems related to hydropower dams. We found that variations in water flow and water depth coupled with increased nutrient availability are major variables that contribute to structural and functional ecosystem changes. We also found that ecological models are an important tool to assess the impact of hydropower dams. For instance, model simulation of different scenarios (e.g., with and without the dam, different operation methods) can analyze and predict the related ecosystem shifts. However, one of the remaining shortcomings of these models is the limited capacity to separate dam-related impacts from other anthropogenic influences (e.g., agriculture, urbanization). Moreover, collecting sufficient high-quality data to increase the statistical power remains a challenge. The severely altered conditions (e.g., generation of very deep lakes) also lead to difficulties for standardized data collection. We see future opportunities in the integration of models to improve the understanding of the different processes affected by hydropower dam development and operation, as well as the use of remote sensing methods for data collection.
\end{abstract}

Keywords: food web models; habitat suitability models; integrated models; water quality models; hydrodynamic models; hydropower dams

\section{Introduction}

Human population growth and economic development cause increasing demands for energy. Hydropower is a renewable and inexpensive source of energy [1-3] that already contributed to about $16 \%$ of the global electricity production in 2011 [4]. Dams have been continuously constructed for hydropower generation and other purposes [5-7]. Until 2016, there were globally about 58,402 large dams (i.e., with heights over than $15 \mathrm{~m}$ ) in operation of which 9595 were primarily designed for hydropower generation [8]. Hydropower dams are typically designed and operated to maximize the energy production and/or to regulate the water flows in order to protect human settlements, as well 
as aquatic ecosystems from drought and inundations [3]. However, besides these assets, hydropower dams can have adverse effects on the structure and functioning of aquatic ecosystems [5,7,9].

Dam construction is considered as one of the major pressures contributing to the modification of natural river ecosystems [10,11]. Scientists and engineers have developed numerous methods for mitigating the environmental impact of dams, such as the installation of pool-type fish passes, or nature-like bypass channels to facilitate the up- and down-stream migration of fish. However, not all adverse impacts can be reduced through the implementation of such mitigating measures [12]. As such, the negative impacts of dams on freshwater ecosystems can be severe and difficult to restore [13]. Therefore, an ecological impact assessment of hydropower dams on the river ecosystems before construction, during operational phases and after dam removal is highly recommended. A thorough understanding of the trade-offs between water for the environment (ecological aspect) and water for hydropower in regulated rivers (socio-economic aspect) is needed in the decision-making about the planning, policy and operations of hydropower dams $[14,15]$. In this context, ecological models can help to conceptualize the potential effects of constructing a hydropower dam on the surrounding ecosystem.

Ecological models can support decision making in environmental and conservation management [16] and have already been applied to assess the impact of dams on fish [17-22], macroinvertebrates [23-25], amphibians [26] and vegetation [27-29]. Models are being increasingly used in environmental assessment, planning and management [30]. However, the type of model implemented, the variables included and the parameterization used strongly differ between different studies. For instance, Freeman et al. [31], Ruetz and Jennings [32] and Rosenfeld et al. [33] used depth, substrate and flow characteristics as input variables in order to assess the impact of altered flow regimes on the habitat suitability of juvenile fish. Kunz [34] used dissolved oxygen and nutrient compounds as input variables to develop a water quality model taking into account the impact of a tropical reservoir. Also regarding the biological communities that are used to quantify the water quality, there is no consensus [35]. There is a general agreement that biological communities serve as the most optimal integrators, and thus, different studies have used different biomonitoring strategies. For example, Fullerton [36], Gore and Hamilton [37], Wu et al. [38] and Bondi et al. [39] assessed the impacts of hydropower dams on the survival of fish (Salmon), macroinvertebrates and diatom diversity and the habitat suitability of frogs, respectively.

In the present research, we reviewed scientific literature that investigates the impact of hydropower dams on river ecosystems by means of ecological models. We aimed to understand what types of data have been used and what type of models, parameterization and validation were implemented. In particular, we investigated the limitations and opportunities of these models. By doing so, we were able to provide some examples of models and listed potential improvements (i.e., recommendations) for future research. Based on the knowledge gained while going through the scientific literature, we compared the applied methods to assess the impact of hydropower dams by means of ecological models. Prior to this, we describe the complex interactions involved in the potential impacts of hydropower dams on freshwater aquatic ecosystems based on the Driver-Pressure-State-Impact-Response (DPSIR) framework.

\section{Methodology}

The European Environment Agency's DPSIR framework [40] describes the chain of causal links between 'Drivers' (social, demographic and economic developments) and 'Pressures' on the environment. The 'Pressures' cause changes to the current or future 'State' of the environment. These environmental changes lead to positive or negative 'Impacts', and the 'Response' is the action taken to solve potential environmental problems. The DPSIR framework was applied to water resources management, river basin management [41-44], river restoration [45] and biodiversity conservation [46]. In this study, we review the most relevant articles. Subsequently, we applied the DPSIR framework to describe the complex interactions involved during the operation and construction of hydropower dams.

In order to provide an overview of the different model approaches that assessed the impacts of hydropower dams on river ecosystems, a search for articles was performed on the Institute for 
Scientific Information (ISI) Web of Science (http:/ / apps.webofknowledge.com). Articles were derived from a search on the ISI Web of Science using search topic $=$ 'hydropower dam*' AND topic $=$ 'habitat ${ }^{* \prime}$. A sub-search was performed using topic $=$ 'model ${ }^{* \prime}$ AND document type $=$ article. Fifty-six key articles were extracted, but those dealing with terrestrial ecology and papers in which insufficient detailed information on the model development process was given were discarded. Finally, thirty-two articles were retained. In this work, we focus on four major questions: (1) what types of modelling approaches were applied for ecological impact assessment; (2) which input variables were used; (3) how were models validated; and (4) how can models be applied? Based on 32 articles, we listed all main input variables that were used; the type of model approaches; the model validation process and the output of the model. Afterwards, we developed an integrated conceptual model that illustrates the linkages between the main input variables, model approaches, the output variables and biotic, abiotic interactions in the ecosystems related to hydropower dams.

Different modelling approaches have been used to assess the impact of hydropower dams on the aquatic ecosystem. To further explore the potential of ecological models in hydropower dam impact assessment, an analysis of Strengths, Weaknesses, Opportunities and Threats (SWOT) was implemented. This assessment provides an overview of the advantages and limitations of models that have been developed and identifies the challenges and opportunities for future studies that aim to assess the impact of hydropower dams.

\section{Results and Discussion}

\subsection{Impacts of Hydropower Dams on Aquatic Ecosystems}

The DPSIR framework relates the socio-economic drivers, pressures, changing state and impacts on river systems and potential actions that can be taken to minimize the ecological problems caused by hydropower dams (Figure 1).

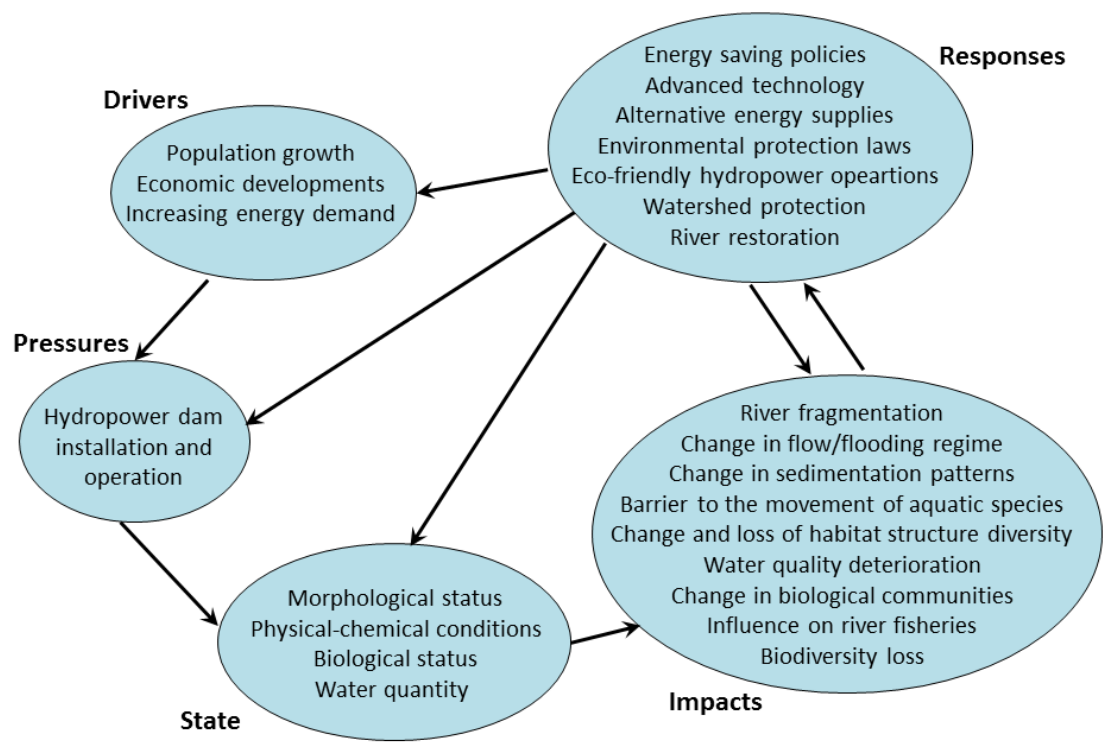

Figure 1. Drivers-Pressures-State-Impacts-Responses framework presenting the impact of hydropower dams on the ecological water quality and habitat suitability for aquatic biological communities.

\subsubsection{Drivers}

The rapid growth of human population, economic development, climate change and the need to close the electricity access gap have stimulated the search for renewable energy such as hydropower, wind, waves, tides, biomass and biofuels [4]. Hydropower is considered as an inexpensive and renewable energy source [7] because it uses the water from the river to generate electricity and 
produces lower amounts of greenhouse gases compared to hydrocarbon-fueled power generation [47]. Hydropower has an advantage over other renewable sources as it can respond rapidly to energy demands, has a high storage capacity and is a more stable and reliable means of generating electricity. Other benefits of hydropower dams include their use for flood control, irrigation and water supply. Furthermore, the creation of reservoirs offers a variety of recreational opportunities such as fishing, swimming and boating [48,49]. The (global) increase in energy demand is the main driver that triggers the construction of hydropower dams. Especially, future hydropower development is expected to be primarily concentrated in the developing countries and the emerging economies of Southeast Asia, South America and Africa [4].

\subsubsection{Pressures}

Despite their economic benefits, the civil works during the construction of the dams such as the road development, powerhouse building and inlet construction impact the surrounding river ecosystem [50]. Moreover, once installed and in operation, dams interrupt the natural river continuum [51], and this can lead to changes in the natural flow regime, in hydraulic conditions in general, in sediment supply and, consequently, in the composition of biological communities $[52,53]$.

\subsubsection{State}

Dam construction and operation are pressures that can cause changes in the state of river geomorphology [47] and hydrology [54]. Furthermore, the construction and presence of hydropower dams can affect the physical-chemical and morphological conditions in a river and thus alter the habitat suitability for riverine communities $[18,55]$. In other words, several alterations in the hydromorphological and chemical status can eventually lead to shifted composition in biological communities [56,57].

An impact of dam operation that changes the state is hydropeaking, i.e., the frequent, rapid and short-term fluctuations in flow and water levels. It is one of the main stressors on aquatic ecosystems [58] as it can, despite its intermittent nature, modify stream banks and channel morphology, water depth, wetted area, velocity distribution, substrate composition, suspended matter, temperature, habitat structure and heterogeneity [59].

Organisms are physiologically, anatomically, morphologically and behaviorally adapted for survival in a specific habitat. Thus, the creation or modification and/or destruction of their preferred habitats can either lead to their extinction or movement to another suitable part of the river catchment [53]. In addition, dams can alter periphyton biomass [10], provoke changed phytoplankton densities [60] and cause algal blooms [61]. Moreover, hydropower dams affect the taxonomic and trophic structure of fish communities and can cause a reduction of fish species richness $[62,63]$ and abundance $[64,65]$.

\subsubsection{Impacts}

Hydroelectric facilities can dramatically affect the aquatic biota. For example, fish and other organisms can be injured or killed by turbine blades [66]. Dams also block migration routes for migratory fish [67-69], isolating populations and increasing their risk of extinction [70]. Moreover, dam construction and operation have also been shown to have a significant impact on microzooplankton richness [60] and the density and composition of macroinvertebrate communities [10,25]. As phytoplankton, zooplankton and invertebrates are important food sources for fish and other vertebrates, changes in food availability affect fish growth and survival [55], as well as the reproduction of key species [26]. Moreover, modifications of physical-chemical water quality may deteriorate spawning grounds and nursery areas [64], leading to biodiversity loss [71], and alter species interaction [72] and ecosystem processes [73].

As damming affects the morphological and hydrological conditions of the river, changes in sediment transport [74], water depth, water temperature [50] and stream velocity [32,75-77] are observed. Moreover, in some cases, huge amounts of sediment that are highly contaminated with heavy metals, organic matter 
and pesticides can be deposited in the reservoir [78,79]. In addition, water level variation due to power generation can propagate and create changes in the tidal regime for very long distances [80,81].

The reservoir itself may undergo the effects of eutrophication processes, such as algae blooms and floating plant accumulations [71]. The increase in water residence time, eutrophication and decomposition of organic matter can moreover cause the increase of toxicants present upstream of a dam. The toxicants may be transported downstream by future floods and intensive rainfall events.

As damming of rivers is used for multiple purposes (i.e., agricultural irrigation, flood control, hydropower generation and recreation), not all environmental impacts associated with dams can be directly attributed to hydroelectric power. Thus, the assessment of the environmental impacts of a specific hydropower facility requires case-by-case review [82] to determine the affected ecosystem services and related socio-economic consequences of the status changes.

\subsubsection{Responses}

The response includes all actions necessary to avoid or control the potential adverse environmental and socio-economic impacts concerning hydropower projects and enhance environmental opportunities [40]. The response related to drivers for dam construction is lower energy demand and/or alternative energy sources. For example, many European countries (e.g., Italy and the United Kingdom) are applying energy-saving policies such as interruptible tariffs or time of day pricing [83]. Another management strategy is promoting the use of advanced technology (e.g., energy-saving building and appliances) in order to reduce energy consumption [84]. In addition, the government should apply the policies to encourage people to use alternative renewable-energy resources such as solar power, wind power and biomass [85]. To reduce the pressure of hydropower dams, the management options also include the development and application of environmental laws to hydropower projects; for example, the performance of the dam project is evaluated, and its license to operate is either revoked or continued [86].

Literature shows that the impact of dams depends on the location, design and operation [87]. Compared to the large dams built for irrigation, water supply and flood control, dams built for hydropower have separate objectives, involve distinctive components, respond to unlike markets and are operated in different ways [5]. Therefore, run-of-the-river and pumped-storage hydroelectric systems, which are alternatives to classic hydropower dams, can minimize impacts related to damming construction [88]. If a dam with a storage reservoir needs to be constructed, it is important to consider the location of the dam, because the building of a dam in regions with high endemism would become more harmful to imperiled aquatic resources [89]. The dam design is also important, as fish passage highly depends on dam design [90,91].

To maintain and/or restore the initial state of the environment, we need to control and minimize the impacts of dam construction and operation [40,92]. Examples are ecologically-sound dam management through the timely release of environmental flows [93] and changes in release patterns and operation schemes [94,95], which aim to improve environmental flows and minimize hydropeaking impacts. For dams with a considerable storage reservoir, the hydropower generation interruptions could be replaced with temporal increases of flow release. This offers more protection to the most vulnerable stream sections, while maintaining the natural flow paradigm in rivers affected by hydropeaking [96]. In addition, the impacts can be mitigated by river restoration actions such as removing migration barriers and then restocking rivers $[97,98]$.

\subsection{Models for Hydropower Dam Impact Assessment}

Table 1 provides a synopsis of the ecological modelling approaches that have been developed to assess the impact of hydropower dams on aquatic habitats. The models were reviewed per aquatic community based on modelling approaches, input variables (geomorphology, hydrology, meteorology, physical-chemistry and biology) and model validation. 
Table 1. Summary of reviewed articles that used models as a tool to assess the impact of hydropower dams on habitat suitability.

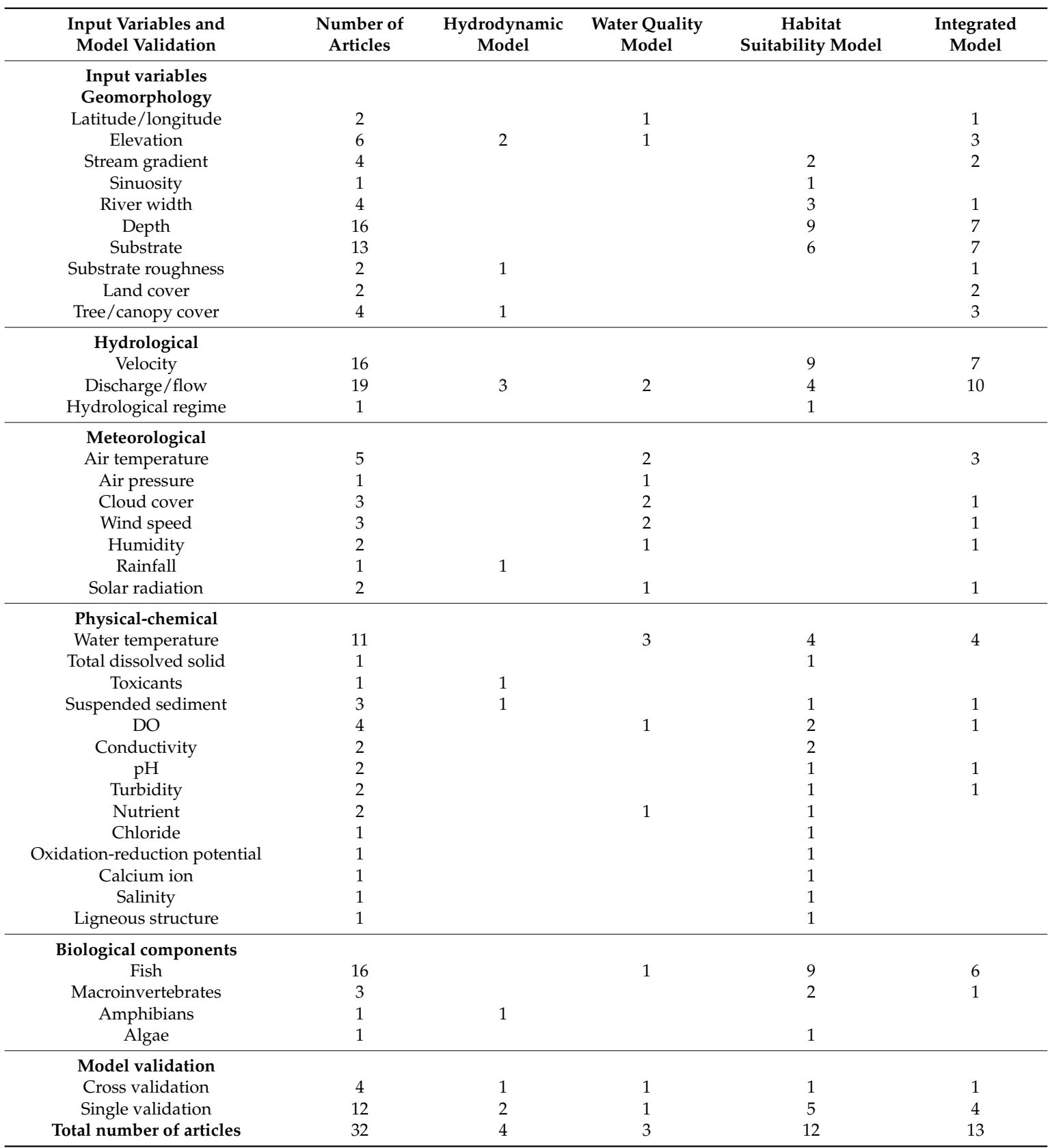

\subsubsection{Model Approaches and Practical Application}

Considering the articles reviewed in this paper, hydropower dam assessment models can be divided into four categories: hydrodynamic models, water quality models, habitat suitability models and integrated models. Integrated models combine two or more models (Table 1; Table S1). Among the reviewed articles, four papers used hydrodynamic models, and three authors used water quality models to assess the impact of hydropower dams on the river morphology and on the physical-chemical quality of the river. Sinokrot and Gulliver [76] used a water quality model to determine the impact of flow variation caused by hydropower dam operation on the river water temperature. A habitat suitability model was used in 12 papers to evaluate the impact of the changes in physical-chemical conditions on the habitat of biotic communities. Li et al. [99] used water depth, velocity and water temperature as input variables in their habitat suitability model to calculate the 
minimum flow needed for fish habitat conservation. The majority of articles (13) used an integrated model (i.e., most were an integration of hydrodynamic and habitat suitability models), in which the impact of hydropower dam construction on river morphology was linked to water quality, food web ecology or biological preferences (Table 1). There was no individual food web model; however, in one paper, it was considered as a part of an integrated model.

Models were also used to assess the success of restoration and mitigation actions on habitat suitability of fish (e.g., Bartholow et al. [100]; Fullerton et al. [36]) and macroinvertebrates (e.g., Gore and Hamilton [37]). Particularly, linear regression, generalized additive models, partial least square regressions, polynomial expressions, fuzzy logic, decision trees, agent-based models, mass balance equations and numerical models were applied to evaluate the impacts of hydropower dam operations on the biota (Table S1). Bartholow et al. [100] applied a one-dimensional hydrodynamic model coupled with a water temperature model. They used the model to assess if the growth and survival of brown trout could be improved via thermal habitat enhancement by providing an understanding of flow effects on temperature. Habitat suitability models and integrated models were mainly developed to support decision making related to the management of multifunctional dams (e.g., hydropower generation, water supply) and fish habitat conservation related to flow management (e.g., minimal flow requirements). Owen et al. [101] used stream flow to construct fuzzy membership functions in order to model variability in experts' perceptions associated with reservoir operation for hydropower generation, fish habitat, recreation (kayaking) and scenery preservation.

\subsubsection{Input Variables}

There is a wide spectrum of environmental variables that can change over time and space [102]. The complex task of dam impact assessment needs careful selection, interpretation and weighting of a multitude of biotic and abiotic information by means of models and expert knowledge [94,103]. It has been highlighted that the model outcome depends on the assumptions made in the pre-processing steps of the modelling process [104]. Therefore, before developing the models, it is necessary to select appropriate input variables [105-107]. A total of 36 different input variables were used, which can be classified as (1) geomorphological, (2) hydrological, (3) meteorological and (4) physical-chemical (Table 1). The number of input variables used per study ranged from one to fifteen, but in case variable selection was performed, three to six variables were retained in the model. Mainly morphological (e.g., depth, substrate), hydrological (e.g., flow, velocity) and physical-chemical variables (e.g., dissolved oxygen) were implemented. Nineteen reviewed articles used flow (discharge) and 16 papers used hydro-morphological variables related to flow (e.g., depth, velocity) as input variables. Eleven papers used water temperature and 13 papers used substrate and less than five papers used meteorological data as input variables. Many hydro-morphological data such as depth, substrate, river flow, velocity and dissolved oxygen are easy to collect and moreover often freely available in databases. Water depth and current velocity are important factors for spawning habitat [33]. Moreover, the velocity/depth ratio may be the best determinant of habitat type and is the most distinct among habitat types [108]. However, $\mathrm{pH}$, biological oxygen demand, metal concentration and nutrient concentrations are key factors affecting the presence of aquatic organisms (e.g., macroinvertebrates), but seemed in most cases neglected in ecological impact assessments. Therefore, those variables should be monitored and included in the models [109] as they may contribute to a better assessment of ecosystem alterations and may improve model predictive performance.

\subsubsection{Model Processes and Outputs}

The models have been used to assess the impacts of hydropower dams at various spatial and temporal scales. Existing ecological models are able to assess the impact of changing hydrological regimes and water quality on the habitat suitability of fish, macroinvertebrates and algae (e.g., Fullerton et al. [36], Kocovsky et al. [110], Quiroga et al. [111]). 
Flow is the key driver in hydropower dam modelling processes (Figure 2). Flow is used as the input variable for hydrodynamic and water quality models to predict the physical and chemical impacts such as a change in water depth, velocity and other variables that are driven by flow regulations $[25,47,112,113]$. In some cases, outputs from water quality or hydrodynamic models have been used as the input variables to predict the impact of dams on habitat suitability. For example, Krause et al. [77] used models to assess the impact of flow manipulation by hydropower on water temperature. Subsequently, they used the simulated water temperature as an input variable to assess the habitat suitability of fish. On the other hand, flow has also been used to predict the habitat suitability of fish [114] or macroinvertebrates [115]. In addition, biotic variables such as the biomass of invertebrates was used as an input variable in food web models to predict the changes in vertebrate communities [55].

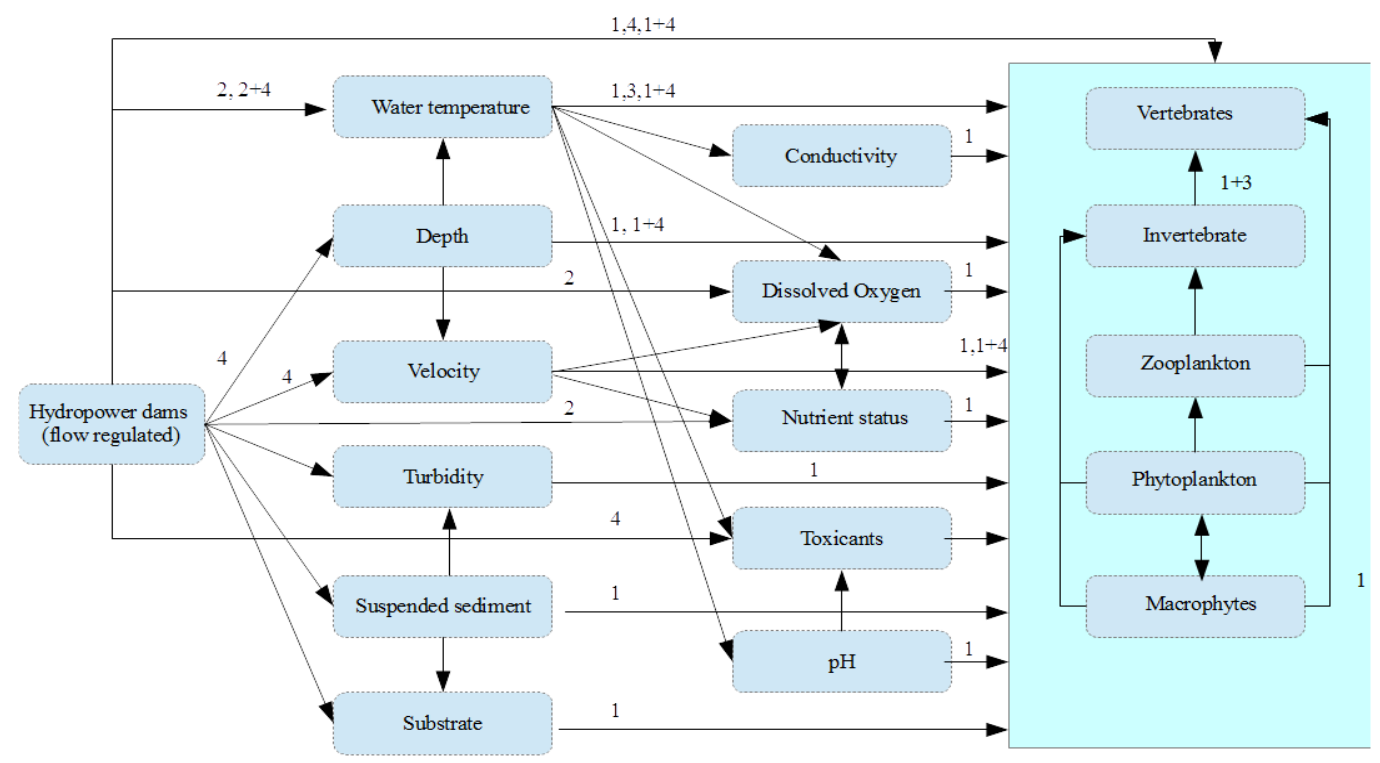

1: Habitat suitability models; 2: Water quality models; 3 : Food web models, 4:Hydrodynamic models

Figure 2. Overview of main input variables used for the models and a representation of the biotic and abiotic interactions related to hydropower dams. The arrows point from an input variable to an output variable. The output variables are quantified as abundance, occurrence (presence/absence), richness, relative density, habitat suitability index and diversity indices (Table S1). The number indicates the type of model implemented: habitat suitability model (1); water quality model (2); food web model (3) and hydrodynamic model (4); (+) indicates the integrated approach.

\subsubsection{Model Validation}

The validation of an ecological model is a testing process to check whether the model is acceptable for the intended purpose [116]. As such, model validation is an indispensable step prior to model acceptance [117]. A good way to validate a model is a comparison of simulated data with observed data of the real system. If the output of a model corresponds to the observed data, then the model is an adequate representation of the system [118]. In case field data are lacking, model validity can be supported by expert insights on model behavior and results. Ecological models are often built for understanding (e.g., scientific research, practical management) and prediction (forecasting) purposes. Although an ecological model conceptualizes real life processes [105], it is often not feasible to integrate all assumptions. In the reviewed papers, models were validated using an independent test set (12 papers) or a cross-validation procedure (four papers). In sixteen papers, no model validation procedure was reported. For example, Quiroga et al. [111] developed a model to predict the loss of fish habitat by the construction of two larger hydropower dams, but no model validation was performed 
due to a lack of validation data. Classic model validation included a model comparison between predictions and observations from an independent dataset [62]. Alternatively, models were validated by comparing results with field observations from a similar ecosystem $[37,77]$.

\subsection{Strengths-Weaknesses-Opportunities-Threats Analysis}

Various models have been developed to get insight into the impact caused by hydropower dam construction and operation. However, within the range of approaches that have been implemented and described in the literature, no best practice for model development, validation and use could be found. Model selection in the reviewed papers was based on the preference of the model developers and on objective parameters (e.g., Cohens kappa, Akaike Information Criterion (AIC)). Often, site-specific criteria decide which approach is most suitable. In order to select the right model, a holistic approach is needed, considering the interplay between many elements such as the purpose of the model, the type of data present, the available knowledge [119] and the model outputs that are required [16]. Hence, the selection of an appropriate model should not only depend on statistical considerations [105,120,121]. Overall, good modelling practices include: (i) the formulation of a clear purpose and research question; (ii) making adequate assumptions and considering their impact on the results; and (iii) an appropriate model evaluation [30]. Modelling results should be easy to present to different stakeholders and should be widely applicable [122]. We used a Strengths-Weaknesses-Opportunities-Threats (SWOT) analysis to discuss the challenges and opportunities of applying ecological models to assess the impact of hydropower dams (Table 2).

Table 2. SWOT analysis of models used in studies on hydropower dam impact assessment.

\begin{tabular}{|c|c|c|}
\hline & Strengths & Weaknesses \\
\hline- & $\begin{array}{l}\text { Suitability for exploring various types of } \\
\text { dam impacts }\end{array}$ & $\begin{array}{l}\text { - Does not take into account the relevant biotic } \\
\text { and abiotic interactions }\end{array}$ \\
\hline \multirow[t]{2}{*}{-} & Explore water quality and habitat suitability for & - $\quad$ Non-transparent variable selection \\
\hline & different dam management strategies & - $\quad$ Lack of clear statistical criteria to assess the \\
\hline \multirow[t]{2}{*}{-} & Enabled syntheses of expert knowledge and & models and related thresholds \\
\hline & empirical data & Lack of model validation \\
\hline- & Applicable at different scales & $\begin{array}{l}\text { - Predicts biotic responses (e.g., abundance, } \\
\text { survival) using a limited number of variables. } \\
\text { Model assumptions may not be valid in } \\
\text { some situations }\end{array}$ \\
\hline & & $\begin{array}{l}\text { - Some models are either too complex or } \\
\text { overly simplified. }\end{array}$ \\
\hline & & Models a low number of data \\
\hline & Opportunities & Threats \\
\hline \multirow[t]{2}{*}{-} & Increasing environmental data quality & Over- or under-prediction \\
\hline & and availability & - $\quad$ Expenses for data collection \\
\hline- & $\begin{array}{l}\text { Growing interest and technical advances in } \\
\text { ecological modelling }\end{array}$ & $\begin{array}{l}\text { Extrapolation of the model to other regions, } \\
\text { biotic element and spatial scale }\end{array}$ \\
\hline- & $\begin{array}{l}\text { Integrated models become better and } \\
\text { more reliable }\end{array}$ & \\
\hline
\end{tabular}

\subsubsection{Strengths}

One of the main strength of using models in hydropower dam impact assessment is to perform scenario-based analyses to explore the change of water quality and habitat suitability under different dam construction, management and operation strategies. Kunz et al. [34] found for instance that daily discharge data could be used to evaluate the effect of future changes in riverine sediment and nutrient concentrations on water quality. Hatten and Batt [75] used depth and velocity simulations to predict the distribution of fish under different management scenarios and selected the most successful 
restoration actions. To explore the potential effects of flow variation related to hydropower on amphibians, Yarnell et al. [26] used two-dimensional hydrodynamic modelling to simulate how hydraulic conditions vary between distinctive flow scenarios. In the next step, the output from the flow simulation was used as an input variable for a habitat suitability model to quantify biodiversity loss under several pulsed flow scenarios. A major advantage of model simulations is that they can detect specific adverse effects on the aquatic biota, allowing restoration strategies to be focused [96]. Habitat modelling is a suitable tool to explore the impacts of for example hydropeaking flows on habitat availability, thus improving the understanding of long-term effects of hydropeaking on different life-stages of organisms and their abundance [47].

Models can be used to quantify the ecosystems' disturbance level compared to a given reference state [47]. They can be used for generating baseline data (e.g., simulation of conditions without dam) and predicting the habitat losses or habitat recovery. In addition, models can identify which restoration strategy is best under a variety of alternative management actions. As a consequence, predictive tools allow managers to assess potential outcomes before making costly decisions [36].

The second strength is the possibility to integrate data originating from different monitoring campaigns and knowledge from literature and experts. For instance, meteorological information is easily obtained from meteorological stations, whereas river characteristics such as depth, substrate composition and water temperature can be measured in the field using a standardized sampling protocol with relatively low cost. However, challenges are often encountered when data are collected in large rivers, remote locations and under extremely high flow conditions [119]. In cases where data are lacking or no data are available (e.g., inaccessible location, no pre-impact data available), knowledge-based models are useful tools $[123,124]$ because information can be obtained from the literature or from local and academic expert knowledge. For example, Boavida et al. [47] developed a fuzzy logic model to investigate the effects of hydropeaking on the habitat of fish in the Ocreza River, Portugal. This synthesis of expert knowledge and river engineering allows the use of simulated environmental conditions (e.g., depth, velocity) as predictors. Additionally, data-driven models can be integrated with expert knowledge-based approaches and hence improve model reliability [125]. A final strength of most models is that they can be applied to a wide range of spatial scales varying from small creeks $[55,112]$ to whole river basins [11] or for different time scales $[26,55]$.

\subsubsection{Weaknesses}

A notable weakness of existing ecological models used in hydropower dam impact assessment is that they are, as ecosystem-conceptualizers, often not able to accurately simulate interactions among physical-chemical properties and biological responses. In aquatic ecosystems, there are complex interactions between organisms and their biotic and abiotic environments [126]. Therefore, ecological models should be constructed based on the good understanding of the reactions and the processes of ecosystems [127]. However, the models presented in the selected papers often disregard the complex processes of ecosystems [112]. Although a few models combined two or more model types, no integrated protocol for model development was proposed. Overall, each modelling technique will be able to answer a specific set of research questions, and thus, the selection of the modelling technique is something that should happen prior to taking the in situ samples. The selection of a particular type of models will delimit the expectations one can have from a hydropower dam impact assessment.

Understanding which factors are important, as well as being able to describe the interaction between factors will help managers to determine the potential management strategies [77]. For instance, flow alteration causes changes in water temperature [76,77], and this change in temperature also affects other variables such as $\mathrm{pH}$ and dissolved oxygen. These relational shifts can influence the survival, growth and reproduction of aquatic species [26]. Most of the models reviewed in this paper have not taken important ecological control mechanisms into consideration (such as nutrient competition or the effect of zooplankton feeding on phytoplankton concentrations). Hydrodynamic models and water quality models only predict the changes of the physical-chemical water quality of the river, 
but often lack biological components. Several water quality models considered the impact of discharge on water temperature, but did not elucidate how temperature changes influence aquatic biota or how fluctuations in flow determined the habitat of aquatic biota. To assess the effect on aquatic biota, these water quality models should be coupled with habitat suitability models.

Most papers often just represented one piece of the complicated processes related to the impact of hydropower dams and may have left out other relevant processes and interactions. For example, Sinokrot and Gulliver [76] studied the impact of changing flows on river water temperatures, but they did not address the impact of temperature changes on aquatic habitat or the impact of flow fluctuations on the aquatic habitat or aquatic species. Although Yarnell et al. [26] determined habitat suitability based on the abiotic or biotic conditions for a single target species or life stage, their models were not able to analyze the interaction of environmental variables on the survival, growth and successful reproduction of a particular species. Moreover, Null et al. [128] used estimates of suitable fish habitat for an entire river; however, habitat segments were not all connected in their analysis. Therefore, model prediction may be an overestimation of the habitat for anadromous fish or other migratory species. Moreover, Null et al. [128] estimated fish habitat that is linked to fish population dynamics as single measures of population response. However, population-level changes can have interactions with habitat modification. The model, therefore, fails to represent this aspect [129]. Several models were not able to predict future densities of populations because the models did not account for the effect of non-hydraulic factors (e.g., temperature, riparian conditions and food availability) on the survival and ultimately future population dynamics of aquatic species [39].

Another weakness occurring when using ecological models for hydropower dam impact assessment is the non-transparent variable selection. In the reviewed papers, models often used just a few hydraulic (velocity, flow) and hydromorphological (water depth, substrate) characteristics to define habitat suitability. For instance, Pert and Erman [130] simply used water depth and average velocity in a 20-m reach of the river to define habitat preference for rainbow trout due to the difficulty in collecting information on other habitat characteristics. Although the outcome of the model was valid, the authors suggested considering other factors related to hydropower dam operation such as the time during the day (morning, afternoon) and long-term changes in discharge.

When using models, challenges in exploring the effects of hydropeaking remain because it is strongly site-specific and also depends on the highly dynamic interactions between hydrology, hydraulics and morphological changes that can be hardly simulated [47]. Boavida et al. [47] have illustrated that hydropeaking impact is strongly dependent on river morphology in fish habitat simulations. Furthermore, Li et al. [113] suggested that the variation of hydrologic frequency, as well as the maximum and minimum amount of water release from dams due to hydropeaking, should be taken into account in model development. In many cases, there will be an overlapping effect of general river regulation and hydropeaking impacts; thus, stressors are difficult to disentangle [47].

Environmental impacts of dams affect different life stages and different groups, which requires a different level of detail in model development. Nevertheless, most model approaches base their assessment on physical-chemical water quality or the habitat suitability of adult fish (e.g., Ruetz and Jennings [32]; Freeman et al. [31]; Cerny et al. [62]; Grand et al. [55]; Hatten et al. [22]; Garcia et al. [18]; Li et al. [99]; Cioffi and Gallerano [112]; Chen et al. [131]; Wang et al. [25]), including often purely the most common and economic valuable species (e.g., trout, salmon) or endangered species. One publication considered the impact of flow regulation on algae [38]; one paper focused on the effect on habitat suitability of amphibians [26]; and just three papers considered macroinvertebrates $[25,37,115]$ in their assessment.

Another weakness is the lack of clear statistical criteria to assess the model fit. In addition, baseline data quantifying the ecological status prior to the building of the dam are often not available, which can result in lack of data for model development and model validation. Moreover, there is no standard sampling protocol available to allow a standardized assessment to investigate the potential impact of a hydropower dam, which is crucial for international comparability. 
Many models made assumptions and simplifications that may not be always valid in a certain condition. For instance, Rheinheimer et al. [14] assumed that gains and losses were neglected from groundwater and from precipitation and evaporation on water bodies, respectively. Grand et al. [55] also assumed that backwater morphology remains constant; however, in reality, flood events can typically occur in the spring and may also occur later in the year. Furthermore, they simplified the calculations of invertebrate production by assuming that the entire invertebrate community can be represented by a single species. Moreover, Vezza et al. [96] did not take into account the effect of biotic interactions. Knowledge of these assumptions provides caution to the model users. These assumptions may result in model uncertainties; thus, documenting these uncertainties, whether quantitatively or qualitatively, allows the model users to propose meaningful strategies for risk management. Moreover, the model's assumptions and simplifications may affect the model's predictability. Therefore, the model should always be evaluated through model validation (cf. Section 3.2.4). We, therefore, recommend that future studies should perform appropriate model validation and document the uncertainties coupled with the model. Furthermore, models can be improved by dealing the relevant assumptions. However, this may result in a complex model that eventually may require additional data.

Models reviewed in this study ranged from very complex to overly simple. Fullerton et al. [36] used numerous model outputs as input data to other models. As the modelling approach is complex, there are many layers of uncertainty (e.g., propagation of error) that are coupled to it. Furthermore, the model requires many different data. However, due to the models' complexity, the model is able to assess various outcomes as there are a variety of metrics that help assess a particular course of action. Conversely, Zhang et al. [132] predicted the water flow using only the rainfall data and included a cyclic function to take into account the evaporation effect. They developed a very simple model that oversimplifies the numerous hydrological processes. As a result, details of other hydrological processes could not be inferred. Examples of relatively simple ecological models were developed by Garcia et al. [18] and Li et al. [113] wherein a limited number of variables was used to predict biotic responses. However, variables not included in the model may have a relevant influence on the biotic responses. Thus, we recommend that careful variable selection should be performed during model development. The choice between a simple and complex model mainly depends on the purpose of the model and the preference of the end users. Although the users are interested in models describing water systems in a detailed manner, the model's functionality and user-friendliness are of paramount importance [107]. Thus, during model development, it is important to take into account the preference of the final users.

Some models were developed based on a relatively low number of data $[78,101]$. This may result in poor model performance and/or model output covering a narrow range of environmental conditions. Future studies should consider standardizing data collection and incorporating additional data to increase the model's reliability.

\subsubsection{Opportunities}

An important opportunity related to the improvement of model prediction capacity is the increasing environmental data availability and data quality. The development of advanced environmental monitoring technologies could result in datasets with a large number of variables with high quality in order to deal with data scarcity and variability when developing models [113]. Many European countries have established environmental monitoring networks to report on their river water quality. Another opportunity is the use of remote sensing methods for data collection. Apart from increased data availability, there has been substantial progress made in ecological modelling with regard to low quality or quantity data. When the amount of data is limited, datasets could be split into a training and validation set [133] in order to test the robustness of the models. Moreover, independent experts could check model performance or the prediction of the model could be evaluated if the model output lies within the reliable ecological limits [120]. Furthermore, the combination of lab results and ecological models [134] and integration of data-driven models [135] can be used to support decision-making in 
water management. When models are used for different scenarios' analysis for which no data exist, a possible way to validate predictions may be through creating different models of the same system and then comparing predictions between models [136], something that is typically applied for the assessment of environmental impact before hydropower dam construction.

To solve the problem of the single impact approach, an integrated model can be applied. For instance, an integrated model that considers physical-chemical, hydraulic and hydro-morphological characteristics could be used to assess the multiple effects related to flow variation on the river ecosystem $[137,138]$. Using an integrated model allows gaining insight into the processes that occur on the river besides the direct impacts observed related to dam construction or wastewater discharges [138]. Models can be used qualitatively and quantitatively to consider climate change impacts on hydropower systems for hydropower relicensing [14]. Given their numerous strengths and opportunities, their use to assess the impact of hydropower dams deserves further investigation. Future studies should explore the potential use of integrated models and the improvement of data collection to reduce the disadvantages of existing models or modelling techniques. Based on the above-mentioned opportunities in combination with technical advances in modelling, it is believed that ecological models can be widely used to support research on hydropower dam impact assessment.

\subsubsection{Threats}

Despite the clear strengths and opportunities of using ecological models in hydropower dam impact assessment, there are also some related threats to their use, especially if the most optimal sequence of the scientific method (i.e., firstly, the formulation of research question, then the selection of modelling techniques, then data collection, subsequently, the model development, then the model validation and, lastly, the interpretation of model outcome) is not followed. The management strategies solely developed based on model results could potentially pose a threat because the output derived from a model can sometimes be inaccurate or deviate from reality. Furthermore, models' outcomes can be overor under-predicted. Li et al. [115] pointed out that the physiology of organisms varies over different life stages, and caution is needed when applying year-round data. Therefore, using one model for different life stages and for the whole-year conditions may lead to incorrect prediction results. Besides hydraulic characteristics, ecological components (e.g., riparian vegetation, present of predators, life stage of organisms), morphological characteristics (e.g., the spectrum of large river systems of the river) $[26,114]$ and physical conditions (e.g., temperature, turbidity, substrate, seasonal variation) $[32,99]$ are important factors that should be taken into account. The study of complex systems thus requires a multi-scale approach, in which it is necessary to consider the interactions occurring across many scales of space, time and organization [136]. Modelers should consider all relevant disturbances and predict various types of impacts before presenting the model output. Nevertheless, stakeholders involved in decision-making processes (e.g., policy makers, water managers, modelers) need to be aware of the uncertainties of the model outputs and the risks/impacts these entail for actions considered. Most of the models to study hydropower dam impacts were developed for particular organisms or a specific location. The habitat suitability criteria used might be suitable for a specific case, but they may not be useful for other locations; therefore, validation of the habitat suitability model on independent data originating from different geographic locations is required [26]. For instance, models developed to assess the impact of small hydropower dams in mountainous streams might not be applicable to assess the impact on large lowland rivers [115]. As a result, the choices of input variables and derived ecological indicators need critical review and validation by local experts before being reliable for model development. Finally, an assessment of hydropower dams based on model simulations has to be carried out with great care because models cannot always separate the dam impact from other anthropogenic influences [63].

\section{Conclusions}

Hydropower dams can affect the hydromorphological, physical-chemical and biological conditions in rivers. The results of our review show that the models applied to assess the impact of hydropower 
dams have been used to analyze and evaluate an expanding range of impacts at various spatial and temporal scales. Existing ecological models provide a basis to assess the impact of changing hydrological regimes and water quality on the habitat suitability of fish, macroinvertebrates and algae caused by the installation and operation of hydropower dams. Despite their numerous strengths and opportunities, these models have inherent weaknesses such as not taking into account the biotic and abiotic interactions; non-transparent variable selection; lack of clear statistical criteria to assess the models and related thresholds; lack of model validation; use of a limited number of variables to assess biotic responses (e.g., abundance, survival) and too complex or overly simple models. These models can be further explored, improved and optimized. For the future, the potential use of integrated models and improved data collection, for instance, by using remote sensing methods should be explored to reduce the disadvantages of existing models or modelling techniques in hydropower dam impact assessment. Based on our review, a limited number of modelling approaches was applied. Thus, we recommend the exploration of other modelling approaches (e.g., Bayesian belief networks, artificial neural networks and random forest). Furthermore, appropriate model validation should be performed to evaluate the model's predictive performance. The model's uncertainties should be documented, and relevant variables should be systematically and prudently selected. These types of models can be improved by more explicitly defining the model's assumptions and incorporating relevant biotic and abiotic interactions. However, by making the model more realistic, the addition of extra biological processes will increase the complexity [55]. Complex models may increase computational time, and additional data may be required. On the other hand, simple models are less costly and easier to interpret; therefore, in general, they are user-friendly. Consequently, in order to select the right model or modelling approach, numerous elements must be considered such as purpose of the model, available data and knowledge, the required model output and, most importantly, the preference and expectations of the model users (e.g., also considering budget and timing constraints).

Supplementary Materials: The following are available online at http:/ / www.mdpi.com/2073-4441/10/3/259/s1, Table S1: Summary of 32 reviewed articles that used models as a tool to assess and analyze the ecological impact of hydropower dams.

Acknowledgments: Thi Hanh Tien Nguyen is grateful for the financial support for this work from the Belgian Technical Cooperation (BTC) in the framework of her PhD grant. Marie Anne Eurie Forio is funded by the special research fund of Ghent University to support the Vlaamse Interuniversitaire Raad (VLIR) Ecuador biodiversity network.

Author Contributions: T.H.T.N. did the literature study and drafted and wrote the work. G.E., P.B., E.B., M.V., T.H.T.H. and P.L.M.G. conceptualized, designed and edited the work. G.E. revised the work. M.A.E.F. made an in-depth model literature study, edited and revised the work and prepared the Supplementary Information. P.L.M.G. initiated the study and supervised the work overall.

Conflicts of Interest: The authors declare no conflict of interest.

\section{References}

1. Bratrich, C.; Truffer, B.; Jorde, K.; Markard, J.; Meier, W.; Peter, A.; Schneider, M.; Wehrli, B. Green hydropower: A new assessment procedure for river management. River Res. Appl. 2004, 20, 865-882. [CrossRef]

2. Castelletti, A.; Pianosi, F.; Soncini-Sessa, R. Water reservoir control under economic, social and environmental constraints. Automatica 2008, 44, 1595-1607. [CrossRef]

3. Jager, H.I.; Smith, B.T. Sustainable reservoir operation: Can we generate hydropower and preserve ecosystem values? River Res. Appl. 2008, 24, 340-352. [CrossRef]

4. Zarfl, C.; Lumsdon, A.E.; Berlekamp, J.; Tydecks, L.; Tockner, K. A global boom in hydropower dam construction. Aquat. Sci. 2015, 77, 161-170. [CrossRef]

5. World Commission on Dams. Dams and Development: A Framework for Decision-Making; The Report of the World Commission on Dams; Earthscan Publications Ltd.: London/Sterling, UK, 2000.

6. Bartle, A. Hydropower potential and development activities. Energy Policy 2002, 30, 1231-1239. [CrossRef] 
7. Kumar, A.; Schei, T.; Ahenkorah, A.; Caceres Rodriguez, R.; Devernay, J.-M.; Freitas, M.; Hall, D.; Killingtveit, Å.; Liu, Z. Hydropower. In IPCC Special Report on Renewable Energy Sources and Climate Change Mitigation; Edenhofer, O., Pichs-Madruga, R., Sokona, Y., Seyboth, K., Matschoss, P., Kadner, S., Zwickel, T., Eickemeier, P., Hansen, G., Schlömer, S., et al., Eds.; Cambridge University Press: Cambridge, UK; New York, NY, USA, 2011.

8. International Commission on Large Dams. World Register of Dams. Available online: http:/ / www.icoldcigb.org (accessed on 25 August 2016).

9. Bunn, S.E.; Arthington, A.H. Basic principles and ecological consequences of altered flow regimes for aquatic biodiversity. Environ. Manag. 2002, 30, 492-507. [CrossRef]

10. Tonkin, J.D.; Death, R.G.; Joy, M.K. Invertebrate Drift Patterns in a Regulated River: Dams, Periphyton Biomass or Longitudinal Patterns? River Res. Appl. 2009, 25, 1219-1231. [CrossRef]

11. Zhai, H.; Cui, B.; Hu, B.; Zhang, K. Prediction of river ecological integrity after cascade hydropower dam construction on the mainstream of rivers in Longitudinal Range-Gorge Region (LRGR), China. Ecol. Eng. 2010, 36, 361-372. [CrossRef]

12. Berkamp, G.; McCartney, M.; Dugan, P.; McNeely, J.; Acreman, M. Dams, Ecosystem Functions and Environmental Restoration Thematic Review II.1 Prepared as an Input to the World Commission on Dams, Cape Town. Available online: http://www.damsreport.org/docs/kbase/thematic/tr21main.pdf (accessed on 5 January 2016).

13. Schelle, P.; Collier, U.; Pittock, J. Rivers at risk: Dams and the future of freshwater ecosystems, World wildlife fund (WWF). In Proceedings of the 7th International River Symposium, Brisbane, Australia, 4 September 2004.

14. Rheinheimer, D.E.; Yarnell, S.M.; Viers, J.H. Hydropower Costs of Environmental Flows and Climate Warming in California's Upper Yuba River Watershed. River Res. Appl. 2013, 29, 1291-1305. [CrossRef]

15. Casas-Mulet, R.; Alfredsen, K.; Killingtveit, Å. Modelling of environmental flow options for optimal Atlantic salmon, Salmo salar, embryo survival during hydropeaking. Fish. Manag. Ecol. 2014, 21, 480-490. [CrossRef]

16. Schmolke, A.; Thorbek, P.; DeAngelis, D.L.; Grimm, V. Ecological models supporting environmental decision making: A strategy for the future. Trends Ecol. Evol. 2010, 25, 479-486. [CrossRef] [PubMed]

17. Hatten, J.R.; Parsley, M.J. A spatial model of white sturgeon rearing habitat in the lower Columbia River, USA. Ecol. Model. 2009, 220, 3638-3646. [CrossRef]

18. Garcia, A.; Jorde, K.; Habit, E.; Caamano, D.; Parra, O. Downstream Environmental Effects of Dam Operations: Changes in Habitat Quality for Native Fish Species. River Res. Appl. 2011, 27, 312-327. [CrossRef]

19. Costa, R.M.S.; Martinez-Capel, F.; Munoz-Mas, R.; Alcaraz-Hernandez, J.D.; Garofano-Gomez, V. Habitat Suitability Modelling at Mesohabitat Scale and Effects of Dam Operation on the Endangered Jucar Nase, Parachondrostoma Arrigonis (River Cabriel, Spain). River Res. Appl. 2012, 28, 740-752. [CrossRef]

20. Fjeldstad, H.P.; Uglem, I.; Diserud, O.H.; Fiske, P.; Forseth, T.; Kvingedal, E.; Hvidsten, N.A.; Okland, F.; Jarnegren, J. A concept for improving Atlantic salmon Salmo salar smolt migration past hydro power intakes. J. Fish. Biol. 2012, 81, 642-663. [CrossRef] [PubMed]

21. Ziv, G.; Baran, E.; Nam, S.; Rodríguez-Iturbe, I.; Levin, S.A. Trading-off fish biodiversity, food security, and hydropower in the Mekong River Basin. Proc. Natl. Acad. Sci. USA 2012, 109, 5609-5614. [CrossRef] [PubMed]

22. Hatten, J.R.; Tiffan, K.F.; Anglin, D.R.; Haeseker, S.L.; Skalicky, J.J.; Schaller, H. A Spatial Model to Assess the Effects of Hydropower Operations on Columbia River Fall Chinook Salmon Spawning Habitat. N. Am. J. Fish. Manag. 2009, 29, 1379-1405. [CrossRef]

23. Marchant, R.; Hehir, G. The use of AUSRIVAS predictive models to assess the response of lotic macroinvertebrates to dams in south-east Australia. Freshw. Biol. 2002, 47, 1033-1050. [CrossRef]

24. Molozzi, J.; Feio, M.J.; Salas, F.; Marques, J.C.; Callisto, M. Development and test of a statistical model for the ecological assessment of tropical reservoirs based on benthic macroinvertebrates. Ecol. Indic. 2012, 23, 155-165. [CrossRef]

25. Wang, Z.Y.; Lee, J.H.W.; Xu, M.Z. Eco-hydraulics and eco-sedimentation studies in China. J. Hydraul. Res. 2013, 51, 19-32. [CrossRef]

26. Yarnell, S.M.; Lind, A.J.; Mount, J.F. Dynamic flow modelling of riverine amphibian habitat with application to regulated flow management. River Res. Appl. 2012, 28, 177-191. [CrossRef]

27. Benjankar, R.; Egger, G.; Jorde, K.; Goodwin, P.; Glenn, N.F. Dynamic floodplain vegetation model development for the Kootenai River, USA. J. Environ. Manag. 2011, 92, 3058-3070. [CrossRef] [PubMed] 
28. Egger, G.; Politti, E.; Woo, H.; Cho, K.-H.; Park, M.; Cho, H.; Benjankar, R.; Lee, N.-J.; Lee, H. Dynamic vegetation model as a tool for ecological impact assessments of dam operation. J. Hydro-Environ. Res. 2012, 6, 151-161. [CrossRef]

29. Guarino, E.d.S.G.; Barbosa, A.M.r.; Waechter, J.L. Occurrence and abundance models of threatened plant species: Applications to mitigate the impact of hydroelectric power dams. Ecol. Model. 2012, 230, $22-33$. [CrossRef]

30. Crout, N.; Kokkonen, T.; Jakeman, A.J.; Norton, J.P.; Newham, L.T.H.; Anderson, R.; Assaf, H.; Croke, B.F.W.; Gaber, N.; Gibbons, D.; et al. Chapter Two Good Modelling Practice. In Environmental Modelling, Software and Decision Support; Jakeman, A.J., Voinov, A.A., Rizzoli, A.E., Chen, S.H., Eds.; Elsevier: Amsterdam, The Netherlands, 2008; Volume 3, pp. 15-31, ISBN 978-0-08-056886-7.

31. Freeman, M.C.; Bowen, Z.H.; Bovee, K.D.; Irwin, E.R. Flow and Habitat Effects on Juvenile Fish Abundance in Natural and Altered Flow Regimes. Ecol. Appl. 2001, 11, 179-190. [CrossRef]

32. Ruetz, C.R.; Jennings, C.A. Swimming performance of larval robust redhorse Moxostoma robustum and low-velocity habitat modeling in the Oconee River, Georgia. Trans. Am. Fish. Soc. 2000, 129, 398-407. [CrossRef]

33. Rosenfeld, J.S.; Campbell, K.; Leung, E.S.; Bernhardt, J.; Post, J. Habitat effects on depth and velocity frequency distributions: Implications for modeling hydraulic variation and fish habitat suitability in streams. Geomorphology 2011, 130, 127-135. [CrossRef]

34. Kunz, M.J.; Wuest, A.; Wehrli, B.; Landert, J.; Senn, D.B. Impact of a large tropical reservoir on riverine transport of sediment, carbon, and nutrients to downstream wetlands. Water Resour. Res. 2011, 47. [CrossRef]

35. Karr, J.R. Assessment of Biotic Integrity Using Fish Communities. Fisheries 1981, 6, 21-27. [CrossRef]

36. Fullerton, A.H.; Steel, E.A.; Caras, Y.; Sheer, M.; Olson, P.; Kaje, J. Putting watershed restoration in context: Alternative future scenarios influence management outcomes. Ecol. Appl. 2009, 19, 218-235. [CrossRef] [PubMed]

37. Gore, J.A.; Hamilton, S.W. Comparison of flow-related habitat evaluations downstream of low-head weirs on small and large fluvial ecosystems. Regul. River 1996, 12, 459-469. [CrossRef]

38. Wu, N.; Tang, T.; Fu, X.; Jiang, W.; Li, F.; Zhou, S.; Cai, Q.; Fohrer, N. Impacts of cascade run-of-river dams on benthic diatoms in the Xiangxi River, China. Aquat. Sci. 2010, 72, 117-125. [CrossRef]

39. Bondi, C.A.; Yarnell, S.M.; Lind, A.J. Transferability of Habitat Suitability Criteria for a Stream Breeding Frog (Rana Boylii) in the Sierra Nevada, California. Herpetol. Conserv. Biol. 2013, 8, 88-103.

40. Smeets, E.; Weterings, R. Environmental Indicators: Typology and Overview; Technical Report No 25; European Environment Agency: Copenhagen, Denmark, 1999. Available online: http:/ / www.geogr.uni-jena.de/fileadmin/ Geoinformatik/projekte/brahmatwinn/Workshops/FEEM/Indicators/EEA_tech_rep_25_Env_Ind.pdf (accessed on 9 November 2017).

41. Arias-Hidalgo, M.E. A Decision Framework for Integrated Wetland-River Basin Management in a Tropical and Data Scarce Environment. Ph.D. Thesis, Delft University of Technology, Delft, The Netherlands, 2012.

42. Bell, S. DPSIR = A Problem Structuring Method? An exploration from the "Imagine" approach. Eur. J. Oper. Res. 2012, 222, 350-360. [CrossRef]

43. Sekovski, I.; Newton, A.; Dennison, W.C. Megacities in the coastal zone: Using a driver-pressure-stateimpact-response framework to address complex environmental problems. Estuar. Coast. Shelf Sci. 2012, 96, 48-59. [CrossRef]

44. Vermaat, J.E.; Estradivari, E.; Becking, L.E. Present and future environmental impacts on the coastal zone of Berau (East Kalimantan, Indonesia), a deductive scenario analysis. Reg. Environ. Chang. 2012, 12, 437-444. [CrossRef]

45. Song, X.Q.; Frostell, B. The DPSIR Framework and a Pressure-Oriented Water Quality Monitoring Approach to Ecological River Restoration. Water 2012, 4, 670-682. [CrossRef]

46. Spangenberg, J.H.; Martinez-Alier, J.; Omann, I.; Monterroso, I.; Binimelis, R. The DPSIR scheme for analysing biodiversity loss and developing preservation strategies. Ecol. Econ. 2009, 69, 9-11. [CrossRef]

47. Boavida, I.; Santos, J.M.; Ferreira, T.; Pinheiro, A. Barbel habitat alterations due to hydropeaking. J. HydroEnviron. Res. 2015, 9, 237-247. [CrossRef]

48. US Department of Energy. Benefits of Hydropower. Available online: https://energy.gov/eere/water/ benefits-hydropower (accessed on 5 January 2018). 
49. Beach, E. Hydro Power vs. Solar Power Advantages. Available online: https://sciencing.com/hydro-powervs-solar-power-advantages-6513.html (accessed on 5 January 2018).

50. Bruno, M.C.; Siviglia, A. Assessing Impacts of Dam Operations-Interdisciplinary Approaches for Sustainable Regulated River Management. River Res. Appl. 2012, 28, 675-677. [CrossRef]

51. Graf, W.L. Downstream hydrologic and geomorphic effects of large dams on American rivers. Geomorphology 2006, 79, 336-360. [CrossRef]

52. Meile, T.; Boillat, J.L.; Schleiss, A.J. Hydropeaking indicators for characterization of the Upper-Rhone River in Switzerland. Aquat. Sci. 2011, 73, 171-182. [CrossRef]

53. Hansen, E.H.; Holtedahl, T.; Lye, K.A. Hydropower Development. Environmental Effects Assessment; N-7491; Norwegian University of Science and Technology, Department of Hydraulic and Environmental Engineering: Trondheim, Norway, 2005.

54. Vörösmarty, C.J.; Meybeck, M.; Fekete, B.; Sharma, K.; Green, P.; Syvitski, J.P.M. Anthropogenic sediment retention: Major global impact from registered river impoundments. Glob. Planet. Chang. 2003, 39, 169-190. [CrossRef]

55. Grand, T.C.; Railsback, S.F.; Hayse, J.W.; Lagory, K.E. A physical habitat model for predicting the effects of flow fluctuations in nursery habitats of the endangered Colorado pikeminnow (Ptychocheilus lucius). River Res. Appl. 2006, 22, 1125-1142. [CrossRef]

56. Forio, M.A.E.; Goethals, P.L.M.; Lock, K.; Asio, V.; Bande, M.; Thas, O. Model-based analysis of the relationship between macroinvertebrate traits and environmental river conditions. Environ. Model. Softw. 2017, in press. [CrossRef]

57. Forio, M.A.E.; Lock, K.; Radam, E.D.; Bande, M.; Asio, V.; Goethals, P. Assessment and analysis of ecological quality, macroinvertebrate communities and diversity in rivers of a multifunctional tropical island. Ecol. Indic. 2017, 77, 228-238. [CrossRef]

58. European Union (EU). Managing Natura 2000 Sites: The Provisions of Article 6 of the 'Habitats' Directive 92/43/EEC; Office for Official Publications of the European Communities: Luxembourg, 2000. Available online: http:/ /ec. europa.eu/environment/nature/natura2000/management/docs/art6/provision_of_art6_en.pdf (accessed on 20 October 2017).

59. Scruton, D.A.; Pennell, C.; Ollerhead, L.M.N.; Alfredsen, K.; Stickler, M.; Harby, A.; Robertson, M.; Clarke, K.D.; LeDrew, L.J. A synopsis of 'hydropeaking' studies on the response of juvenile Atlantic salmon to experimental flow alteration. Hydrobiologia 2008, 609, 263-275. [CrossRef]

60. Zhou, S.; Tang, T.; Wu, N.; Fu, X.; Jiang, W.; Li, F.; Cai, Q. Impacts of cascaded small hydropower plants on microzooplankton in Xiangxi River, China. Acta Ecol. Sin. 2009, 29, 62-68. [CrossRef]

61. Lessard, J.; Hicks, D.M.; Snelder, T.H.; Arscott, D.B.; Larned, S.T.; Booker, D.; Suren, A.M. Dam Design can Impede Adaptive Management of Environmental Flows: A Case Study from the Opuha Dam, New Zealand. Environ. Manag. 2013, 51, 459-473. [CrossRef] [PubMed]

62. Cerny, J.; Copp, G.H.; Kovac, V.; Gozlan, R.; Vilizzi, L. Initial impact of the Gabcikovo hydroelectric scheme on the species richness and composition of 0+fish assemblages in the Slovak flood plain, River Danube. River Res. Appl. 2003, 19, 749-766. [CrossRef]

63. De Merona, B.; Vigouroux, R.; Tejerina-Garro, F.L. Alteration of fish diversity downstream from Petit-Saut Dam in French Guiana. Implication of ecological strategies of fish species. Hydrobiologia 2005, 551, 33-47. [CrossRef]

64. Yi, Y.; Wang, Z.; Yang, Z. Impact of the Gezhouba and Three Gorges Dams on habitat suitability of carps in the Yangtze River. J. Hydrol. 2010, 387, 283-291. [CrossRef]

65. Dauble, D.D.; Hanrahan, T.P.; Geist, D.R.; Parsley, M.J. Impacts of the Columbia River Hydroelectric System on Main-Stem Habitats of Fall Chinook Salmon. N. Am. J. Fish. Manag. 2003, 23, 64-659. [CrossRef]

66. Coutant, C.C.; Whitney, R.R. Fish Behavior in Relation to Passage through Hydropower Turbines: A Review. Trans. Am. Fish. Soc. 2000, 129, 351-380. [CrossRef]

67. Han, S.-Y.; Kwak, S.-J.; Yoo, S.-H. Valuing environmental impacts of large dam construction in Korea: An application of choice experiments. Environ. Impact Assess. Rev. 2008, 28, 256-266. [CrossRef]

68. Makrakis, M.C.; Miranda, L.E.; Makrakis, S.; Fontes, H.M.; Morlis, W.G.; Dias, J.H.P.; Garcia, J.O. Diversity in migratory patterns among Neotropical fishes in a highly regulated river basin. J. Fish. Biol. 2012, 81, 866-881. [CrossRef] [PubMed] 
69. Brown, J.J.; Limburg, K.E.; Waldman, J.R.; Stephenson, K.; Glenn, E.P.; Juanes, F.; Jordaan, A. Fish and hydropower on the US Atlantic coast: Failed fisheries policies from half-way technologies. Conserv. Lett. 2013, 6, 280-286. [CrossRef]

70. Navarro, R.S.; Stewardson, M.; Breil, P.; Jalón, D.G.d.; Eisele, M. Hydrological impacts affecting endangered fish species: A Spanish case study. River Res. Appl. 2007, 23, 511-523. [CrossRef]

71. Water Quality Assessments-A Guide to Use of Biota, Sediments and Water in Environmental Monitoring-Second Edition. Chapman, D., WHO (Eds.); 1996; p. 651. Available online: http:/ / www.who. int/water_sanitation_health/resourcesquality/watqualassess.pdf (accessed on 7 January 2016).

72. Allesina, S.; Tang, S. Stability criteria for complex ecosystems. Nature 2012, 483, 205-208. [CrossRef] [PubMed]

73. Chapin, F.S., III; Zavaleta, E.S.; Eviner, V.T.; Naylor, R.L.; Vitousek, P.M.; Reynolds, H.L.; Hooper, D.U.; Lavorel, S.; Sala, O.E.; Hobbie, S.E.; et al. Consequences of changing biodiversity. Nature 2000, 405, 234-242. [CrossRef] [PubMed]

74. Käiro, K.; Möls, T.; Timm, H.; Virro, T.; Järvekülg, R. The effect of damming on biological quality according to macroinvertebrates in some Estonian streams, Central-Baltic Europe: A pilot study. River Res. Appl. 2011, 27, 895-907. [CrossRef]

75. Hatten, J.R.; Batt, T.R. Hydraulic Alterations Resulting From Hydropower Development in the Bonneville Reach of the Columbia River. Northwest Sci. 2010, 84, 207-222. [CrossRef]

76. Sinokrot, B.A.; Gulliver, J.S. In-stream flow impact on river water temperatures. J. Hydraul. Res. 2000, 38, 339-349. [CrossRef]

77. Krause, C.W.; Newcomb, T.J.; Orth, D.J. Thermal habitat assessment of alternative flow scenarios in a tailwater fishery. River Res. Appl. 2005, 21, 581-593. [CrossRef]

78. Jacoub, G.; Westrich, B. Modelling transport dynamics of contaminated sediments in the headwater of a hydropower plant at the Upper Rhine River. Acta Hydrochim. Hydrobiol. 2006, 34, 279-286. [CrossRef]

79. Couillard, C.M.; Macdonald, R.W.; Courtenay, S.C.; Palace, V.P. Chemical-environment interactions affecting the risk of impacts on aquatic organisms: A review with a Canadian perspective-interactions affecting exposure. Environ. Rev. 2008, 16, 1-17. [CrossRef]

80. Jay, D.A.; Leffler, K.; Diefenderfer, H.L.; Borde, A.B. Tidal-Fluvial and Estuarine Processes in the Lower Columbia River: I. Along-Channel Water Level Variations, Pacific Ocean to Bonneville Dam. Estuaries Coasts 2015, 38, 415-433. [CrossRef]

81. Hauer, C.; Holzapfel, P.; Leitner, P.; Graf, W. Longitudinal assessment of hydropeaking impacts on various scales for an improved process understanding and the design of mitigation measures. Sci. Total Environ. 2017, 575, 1503-1514. [CrossRef] [PubMed]

82. Environmental Protection Agency (EPA). Electricity from Hydropower. Available online: http:/ / www.epa. gov / cleanenergy/energy-and-you/affect/hydro.html (accessed on 7 October 2015).

83. Torriti, J.; Hassan, M.G.; Leach, M. Demand response experience in Europe: Policies, programmes and implementation. Energy 2010, 35, 1575-1583. [CrossRef]

84. Omer, A.M. Energy, environment and sustainable development. Renew. Sustain. Energy Rev. 2008, 12, $2265-2300$. [CrossRef]

85. Islam, A.K.M.S.; Islam, M.; Rahman, T. Effective renewable energy activities in Bangladesh. Renew. Energy 2006, 11, 677-688. [CrossRef]

86. Federal Energy Regulatory Commission. Establishing the Length of License Terms for Hydroelectric Projects. 2016. Available online: https:/ / www.federalregister.gov/documents/2016/11/25/2016-28195/establishingthe-length-of-license-terms-for-hydroelectric-projects (accessed on 20 December 2016).

87. Dugan, P. Mainstream dams as barriers to fish migration: International learning and implications for the Mekong. Catch Cult 2008, 14, 9-15.

88. Sternberg, R. Hydropower's future, the environment, and global electricity systems. Renew. Sustain. Energy Rev. 2010, 14, 713-723. [CrossRef]

89. McDonald, R.I.; Olden, J.D.; Opperman, J.J.; Miller, W.M.; Fargione, J.; Revenga, C.; Higgins, J.V.; Powell, J. Energy, Water and Fish: Biodiversity Impacts of Energy Sector Water Demand in the United States Depend on Efficiency and Policy Measures. PLoS ONE 2012, 7, e50219. [CrossRef] [PubMed]

90. Schilt, C.R. Developing fish passage and protection at hydropower dams. Appl. Anim. Behav. Sci. 2007, 104, 295-325. [CrossRef] 
91. Yin, X.A.; Yang, Z.F.; Petts, G.E. Optimizing Environmental Flows Below Dams. River Res. Appl. 2012, 28, 703-716. [CrossRef]

92. Maxim, L.; Spangenberg, J.H.; O'Connor, M. An analysis of risks for biodiversity under the DPSIR framework. Ecol. Econ. 2009, 69, 12-23. [CrossRef]

93. Richter, B.D.; Thomas, G.A. Restoring Environmental Flows by Modifying Dam Operations. Ecol. Soc. 2007, 12. Available online: http://www.ecologyandsociety.org/vol12/iss1/art12/ (accessed on 20 February 2018). [CrossRef]

94. Grill, G.; Dallaire, C.O.; Chouinard, E.F.; Sindorf, N.; Lehner, B. Development of new indicators to evaluate river fragmentation and flow regulation at large scales: A case study for the Mekong River Basin. Ecol. Indic. 2014, 45, 148-159. [CrossRef]

95. Pragana, I.; Boavida, I.; Cortes, R.; Pinheiro, A. Hydropower Plant Operation Scenarios to Improve Brown Trout Habitat. River Res. Appl. 2017, 33, 364-376. [CrossRef]

96. Vezza, P.; Parasiewicz, P.; Spairani, M.; Comoglio, C. Habitat modeling in high-gradient streams: The mesoscale approach and application. Ecol. Appl. 2014, 24, 844-861. [CrossRef] [PubMed]

97. Dudgeon, D. River rehabilitation for conservation of fish biodiversity in monsoonal Asia. Ecol. Soc. 2005, 10. Available online: http:/ / www.ecologyandsociety.org/vol10/iss2/art15/ (accessed on 20 February 2018). [CrossRef]

98. De Groot, S.J. A review of the past and present status of anadromous fish species in the Netherlands: Is restocking the Rhine feasible? Hydrobiologia 2002, 478, 205-218. [CrossRef]

99. Li, R.; Chen, Q.; Ye, F. Modelling the impacts of reservoir operations on the downstream riparian vegetation and fish habitats in the Lijiang River. J. Hydroinform. 2011, 13, 229-244. [CrossRef]

100. Bartholow, J.M.; Campbell, S.G.; Flug, M. Predicting the thermal effects of dam removal on the Klamath River. Environ. Manag. 2004, 34, 856-874. [CrossRef] [PubMed]

101. Owen, W.J.; Gates, T.K.; Flug, M. Variability in perceived satisfaction of reservoir management objectives. J. Water Res. Plan. Manag. 1997, 123, 147-153. [CrossRef]

102. Ruokolainen, L.; Lindén, A.; Kaitala, V.; Fowler, M.S. Ecological and evolutionary dynamics under coloured environmental variation. Trends Ecol. Evol. 2009, 24, 555-563. [CrossRef] [PubMed]

103. Boavida, I.; Dias, V.; Ferreira, M.T.; Santos, J.M. Univariate functions versus fuzzy logic: Implications for fish habitat modeling. Ecol. Eng. 2014, 71, 533-538. [CrossRef]

104. Zuur, A.F.; Ieno, E.N.; Elphick, C.S. A protocol for data exploration to avoid common statistical problems. Methods Ecol. Evol. 2010, 1, 3-14. [CrossRef]

105. Guisan, A.; Zimmermann, N.E. Predictive habitat distribution models in ecology. Ecol. Model. 2000, 135, 147-186. [CrossRef]

106. Everaert, G.; Holguin, J.E.; Goethals, P.L.M. Selecting relevant predictors: Impact of variable selection on model performance, uncertainty and applicability of models in environmental decision making. In Proceedings of the International Congress on Environmental Modelling and Software: Managing Resources of a Limited Planet: Pathways and Visions under Uncertainty, Sixth Biennial Meeting, Leipzig, Germany, 1 July 2012.

107. Forio, M.A.E.; Mouton, A.; Lock, K.; Boets, P.; Nguyen, T.H.T.; Damanik Ambarita, M.N.; Musonge, P.L.S.; Dominguez-Granda, L.; Goethals, P.L.M. Fuzzy modelling to identify key drivers of ecological water quality to support decision and policy making. Environ. Sci. Policy 2017, 68, 58-68. [CrossRef]

108. Jowett, I.G. A method for objectively identifying pool, run, and riffle habitats from physical measurements. N. Z. J. Mar. Freshw. Res. 1993, 27, 241-248. [CrossRef]

109. Hoang, T.H.; Lock, K.; Mouton, A.; Goethals, P.L.M. Application of classification trees and support vector machines to model the presence of macroinvertebrates in rivers in Vietnam. Ecol. Inform. 2010, 5, 140-146. [CrossRef]

110. Kocovsky, P.M.; Ross, R.M.; Dropkin, D.S. Prioritizing Removal of Dams for Passage of Diadromous Fishes on a Major River System. River Res. Appl. 2009, 25, 107-117. [CrossRef]

111. Quiroga, A.P.; Lancelotti, J.L.; Riva-Rossi, C.M.; Tagliaferro, M.; Asorey, M.G.; Pascual, M.A. Dams versus habitat: Predicting the effects of dams on habitat supply and juvenile rainbow trout along the Santa Cruz River, Patagonia. Hydrobiologia 2015, 755, 57-72. [CrossRef]

112. Cioffi, F.; Gallerano, F. Multi-objective analysis of dam release flows in rivers downstream from hydropower reservoirs. Appl. Math Model. 2012, 36, 2868-2887. [CrossRef] 
113. Li, R.; Chen, Q.; Duan, C. Ecological hydrograph based on Schizothorax chongi habitat conservation in the dewatered river channel between Jinping cascaded dams. Sci. China-Technol. Sci. 2011, 54, 54-63. [CrossRef]

114. Enders, E.C.; Scruton, D.A.; Clarke, K.D. The 'Natural Flow Paradigm' and Atlantic Salmon-Moving from Concept to Practice. River Res. Appl. 2009, 25, 2-15. [CrossRef]

115. Li, F.; Cai, Q.; Fu, X.; Liu, J. Construction of habitat suitability models (HSMs) for benthic macroinvertebrate and their applications to instream environmental flows: A case study in Xiangxi River of Three Gorges Reservior region, China. Prog. Nat. Sci. 2009, 19, 359-367. [CrossRef]

116. Rykiel, E.J.J. Testing ecological models: the meaning of validation. Ecol. Model. 1996, 90, 229-244. [CrossRef]

117. Mayer, D.G.; Butler, D.G. Statistical Validation. Ecol. Model. 1993, 68, 21-32. [CrossRef]

118. Boavida, I.; Santos, J.M.; Katopodis, C.; Ferreira, M.T.; Pinheiro, A. Uncertainty in predicting the fish-response to two-dimensional habitat modeling using field data. River Res. Appl. 2013, 29, 1164-1174. [CrossRef]

119. Thuiller, W.; Munkemuller, T.; Moller, A.P.; Fiedler, W.; Berthold, P. Habitat suitability modelling. In Effects of Climate Change on Birds; Oxford University Press: New York, NY, USA, 2010; pp. 77-85.

120. Everaert, G.; Pauwels, I.S.; Boets, P.; Verduin, E.; de la Haye, M.A.A.; Blom, C.; Goethals, P.L.M. Model-based evaluation of ecological bank design and management in the scope of the European Water Framework Directive. Ecol. Eng. 2013, 53, 144-152. [CrossRef]

121. Boets, P.; Pauwels, I.; Lock, K.; Goethals, P. Using an integrated modelling approach for risk assessment of the 'killer shrimp' Dikerogammarus villosus. River Res. Appl. 2014, 30, 403-412. [CrossRef]

122. Conallin, J.; Boegh, E.; Jensen, J.K. Instream physical habitat modelling types: An analysis as stream hydromorphological modelling tools for EU water resource managers. Int. J. River Basin Manag. 2010, 8, 93-107. [CrossRef]

123. Ahmadi-Nedushan, B.; St-Hilaire, A.; Berube, M.; Robichaud, E.; Thiemonge, N.; Bobee, B. A review of statistical methods for the evaluation of aquatic habitat suitability for instream flow assessment. River Res. Appl. 2006, 22, 503-523. [CrossRef]

124. Jørgensen, S.E. Overview of the model types available for development of ecological models. Ecol. Model. 2008, 215, 3-9. [CrossRef]

125. Mouton, A.M.; Baets, B.D.; Goethals, P.L.M. Knowledge-based versus data-driven fuzzy habitat suitability models for river management. Environ. Model. Softw. 2009, 24, 982-993. [CrossRef]

126. Anand, M.; Gonzale, A.; Guichard, F.; Kolasa, J.; Parrott, L. Ecological Systems as Complex Systems: Challenges for an Emerging Science. Diversity 2010, 2, 395-410. [CrossRef]

127. Jorgensen, S.E.; Chon, T.-S.; Recknagel, F. Handbook of Ecological Modelling and Informatics; WIT Press: Southampton, UK, 2009.

128. Null, S.E.; Medellin'-Azuara, J.; Escriva-Bou, A.; Lent, M.; Lund, J.R. Optimizing the dammed: Water supply losses and fish habitat gains from dam removal in California. J. Environ. Manag. 2014, 136, 121-131. [CrossRef] [PubMed]

129. Hayes, D.; Jones, M.; Lester, N.; Chu, C.; Doka, S.; Netto, J.; Stockwell, J.; Thompson, B.; Minns, C.K.; Shuter, B.; et al. Linking fish population dynamics to habitat conditions: insights from the application of a process-oriented approach to several Great Lakes species. Rev. Fish Biol. Fish. 2009, 19, 295-312. [CrossRef]

130. Pert, E.J.; Erman, D.C. Habitat Use by Adult Rainbow-Trout under Moderate Artificial Fluctuations in Flow. Trans. Am. Fish. Soc. 1994, 123, 913-923. [CrossRef]

131. Chen, Q.W.; Chen, D.; Li, R.N.; Ma, J.F.; Blanckaert, K. Adapting the operation of two cascaded reservoirs for ecological flow requirement of a de-watered river channel due to diversion-type hydropower stations. Ecol. Model. 2013, 252, 266-272. [CrossRef]

132. Zhang, Q.; Li, L.; Wang, Y.G.; Werner, A.D.; Xin, P.; Jiang, T.; Barry, D.A. Has the Three-Gorges Dam made the Poyang Lake wetlands wetter and drier? Geophys. Res. Lett. 2012, 39. [CrossRef]

133. Goethals, P.L.M.; Dedecker, A.P.; Gabriels, W.; Lek, S.; De Pauw, N. Applications of artificial neural networks predicting macroinvertebrates in freshwaters. Aquat. Ecol. 2007, 41, 491-508. [CrossRef]

134. Boets, P.; Lock, K.; Messiaen, M.; Goethals, P.L.M. Combining datadriven methods and lab studies to analyse the ecology of Dikerogammarus villosus. Ecol. Inform. 2010, 5, 133-139. [CrossRef]

135. Hoang, T.H.; Mouton, A.; Lock, K.; Pauw, N.D.; Goethals, P.L.M. Integrating data-driven ecological models in an expert-based decision support system for water management in the Du river basin (Vietnam). Environ. Monit. Assess. 2013, 185, 631-642. [CrossRef] [PubMed] 
136. Parrott, L. Hybrid modelling of complex ecological systems for decision support: Recent successes and future perspectives. Ecol. Inform. 2011, 6, 44-49. [CrossRef]

137. Holguin-Gonzalez, J.E.; Everaert, G.; Boets, P.; Galvis, A.; Goethals, P.L.M. Development and application of an integrated ecological modelling framework to analyze the impact of wastewater discharges on the ecological water quality of rivers. Environ. Model. Softw. 2013, 48, 27-36. [CrossRef]

138. Holguin-Gonzalez, J.; Boets, P.; Everaert, G.; Pauwels, I.; Lock, K.; Gobeyn, S.; Benedetti, L.; Amerlinck, Y.; Nopens, I.; Goethals, P. Development and assessment of an integrated ecological modelling framework to assess the effect of investments in wastewater treatment on water quality. Water Sci. Technol. 2014, 70, 1798-1807. [CrossRef] [PubMed]

(c) 2018 by the authors. Licensee MDPI, Basel, Switzerland. This article is an open access article distributed under the terms and conditions of the Creative Commons Attribution (CC BY) license (http:/ / creativecommons.org/licenses/by/4.0/). 